\title{
Raising the Dehydrogenation Rate of a Mg-CMC (Carboxymethylcellulose, Sodium Salt) Composite by Alloying Ni via Hydride-Forming Milling
}

\author{
Myoung Youp Song ${ }^{1, *}$, Eunho Choi ${ }^{2}$, and Young Jun Kwak ${ }^{1}$ \\ ${ }^{I}$ Division of Advanced Materials Engineering, Hydrogen \& Fuel Cell Research Center, Engineering Research Institute, Chonbuk \\ National University, Jeonju 54896, Republic of Korea \\ ${ }^{2}$ Department of Materials Engineering, Graduate School, Chonbuk National University, Jeonju 54896, Republic of Korea
}

\begin{abstract}
In our previous work, samples with a composition of $95 \mathrm{wt} \% \mathrm{Mg}+5 \mathrm{wt} \% \mathrm{CMC}$ (Carboxymethylcellulose, Sodium Salt, $\left[\mathrm{C}_{6} \mathrm{H}_{7} \mathrm{O}_{2}(\mathrm{OH})_{\mathrm{x}}\left(\mathrm{C}_{2} \mathrm{H}_{2} \mathrm{O}_{3} \mathrm{Na}\right)_{\mathrm{y}}\right]_{\mathrm{n}}$ ) (named Mg-5 wt\%CMC) were prepared through hydride-forming milling. Mg-5 wt\%CMC had a very high hydrogenation rate but a low dehydrogenation rate. Addition of $\mathrm{Ni}$ to $\mathrm{Mg}$ is known to increase the hydrogenation and dehydrogenation rates of $\mathrm{Mg}$. We chose $\mathrm{Ni}$ as an additive to increase the dehydrogenation rate of Mg- $5 \mathrm{wt} \% \mathrm{CMC}$. In this study, samples with a composition of $90 \mathrm{wt} \%$ $\mathrm{Mg}+5 \mathrm{wt} \% \mathrm{CMC}+5 \mathrm{wt} \% \mathrm{Ni}$ (named $\mathrm{Mg}-5 \mathrm{wt} \% \mathrm{CMC}-5 \mathrm{wt} \% \mathrm{Ni}$ ) were made through hydride-forming milling, and the hydrogenation and dehydrogenation properties of the prepared samples were investigated. The activation of Mg-5 wt\%CMC- $5 \mathrm{wt} \% \mathrm{Ni}$ was completed at the $3^{\text {rd }}$ hydrogenation-dehydrogenation cycle $(\mathrm{N}=3)$. Mg-5 wt\%CMC-5 wt\% Ni had an effective hydrogen-storage capacity (the quantity of hydrogen stored for 60 $\mathrm{min}$ ) of $5.83 \mathrm{wt} \%$ at $593 \mathrm{~K}$ in 12 bar hydrogen at N=3. Mg-5 wt\%CMC- $5 \mathrm{wt} \% \mathrm{Ni}$ released hydrogen of $2.73 \mathrm{wt} \%$ for $10 \mathrm{~min}$ and $4.61 \mathrm{wt} \%$ for $60 \mathrm{~min}$ at $593 \mathrm{~K}$ in 1.0 bar hydrogen at $\mathrm{N}=3$. Mg-5 wt\%CMC- $5 \mathrm{wt} \% \mathrm{Ni}$ dehydrogenated at $\mathrm{N}=4$ contained $\mathrm{Mg}$ and small amounts of $\mathrm{MgO}, \beta-\mathrm{MgH}_{2}, \mathrm{Mg}_{2} \mathrm{Ni}$, and Ni. Hydride-forming milling of $\mathrm{Mg}$ with $\mathrm{CMC}$ and $\mathrm{Ni}$ and $\mathrm{Mg}_{2} \mathrm{Ni}$ formed during hydrogenation-dehydrogenation cycling are believed to have increased the dehydrogenation rate of Mg-5 wt\%CMC. As far as we know, this study is the first in which a polymer $\mathrm{CMC}$ and $\mathrm{Ni}$ were added to $\mathrm{Mg}$ by hydride-forming milling to improve the hydrogenation and dehydrogenation properties of $\mathrm{Mg}$.
\end{abstract}

(Received June 14, 2018; Accepted June 22, 2018)

Keywords: hydrogen absorbing materials, mechanical milling, scanning electron microscopy (SEM), X-ray diffraction, a polymer CMC (Carboxymethylcellulose, Sodium Salt) addition, Ni addition.

\section{INTRODUCTION}

Magnesium forms magnesium hydride, $\mathrm{MgH}_{2}$, which has high energy density and is a reversible hydride. Magnesium hydride has a high hydrogen capacity (7.66 wt\%). Magnesium is abundantly available and of low cost. However, $\mathrm{MgH}_{2}$ has an unfavorable high hydrogen release temperature (about $573 \mathrm{~K}$ in 1.0 bar hydrogen), slow dehydrogenation kinetics, and a high chemical affinity with air and oxygen [1].

Many studies to improve the hydrogenation and dehydrogenation characteristics of magnesium have been carried out by alloying metallic elements with magnesium

*Corresponding Author: Myoung Youp Song

[Tel: +82-63-270-2379, E-mail: songmy@jbnu.ac.kr]

Copyright (c) The Korean Institute of Metals and Materials or magnesium hydride [2-4], by adding intermetallic compounds [5-8] or carbon materials [9] to magnesium or magnesium hydride, by preparing Mg-based compounds [10-12], and by applying various processing or treatment methods to magnesium or magnesium hydride [13].

Liang et al. [4] reported that mechanical alloying could be used to produce a nanocrystalline $\mathrm{Mg}_{2} \mathrm{Ni}$ intermetallic compound or a nanocrystalline $\mathrm{Mg}$ and $\mathrm{Mg}_{2} \mathrm{Ni}$ composite powder. A $\mathrm{Mg}_{2} \mathrm{Ni}$ intermetallic compound prepared by mechanical alloying could be hydrogenated rapidly without activation process. Activation of the $\mathrm{Mg}+\mathrm{Mg}_{2} \mathrm{Ni}$ composites was required. However, the activated nanocrystalline $\mathrm{Mg}+\mathrm{Mg}_{2} \mathrm{Ni}$ had better hydrogenation kinetics at low temperature $(423 \mathrm{~K})$ than nanocrystalline $\mathrm{Mg}_{2} \mathrm{Ni}$ and had a high hydrogen-storage capacity. Huot et al. [8] synthesized the $\mathrm{MgH}_{2}+$ 
ferroniobium nanocomposites by high-energy ball milling. Their results showed that the ferroniobium alloy is an effective catalyst for hydrogen sorption, mainly with ferroniobium as coarse granulates. They found that the high purity metals are slightly more active catalysts than the ferroniobium alloy for hydrogenation and dehydrogenation of $\mathrm{Mg}$. They explained this behavior is due to the differences in chemical interfacial energies. Tian and Shang [9] incorporated three carbon materials (plasma carbon, activated carbon, and carbon nanotube) into $\mathrm{Mg}$-based composites (TiC-catalyzed $\mathrm{MgH}_{2}$ ) via co-milling. The incorporation of plasma carbon reduced dehydrogenation temperature down to $184 \mathrm{~K}$ and improved the dehydrogenation kinetics of $\mathrm{MgH}_{2} / \mathrm{TiC}$ most effectively. Hydrogenation and dehydrogenation properties of $\mathrm{MgH}_{2}$ were improved by combined nanoconfinement of carbon and catalysis roles. Huot et al. [11] co-milled $\mathrm{Mg}_{6} \mathrm{Pd}$ and $\mathrm{Fe}$ in a high energy mill to improve the hydrogenation and dehydrogenation kinetics. They reported that the presence of iron greatly modifies the hydrogenation properties and the system's microstructure. They insisted that the reduced crystallite size of alloys and hydride phases with the addition of $\mathrm{Fe}$ enhanced hydrogen diffusion and hydrogenation and dehydrogenation properties, and the microstrain was essentially the same with and without iron but it probably plays a role in the hydrogenation and dehydrogenation processes. Xie et al. [12] attempted to explore the ameliorated oxidation resistance through microstructural evolutions during air contact and hydrogenation and dehydrogenation kinetics changes in Mg-based hydrogen storage alloys with different $\mathrm{Ce}$ amounts. They prepared $\mathrm{Mg}$-rich Mg-Ni-Ce alloys by near equilibrium solidification. $\mathrm{CeH}_{2.73}$ was formed after the activation process and reacted with oxygen to form $\mathrm{CeO}_{2}$. They insisted that the formed $\mathrm{CeH}_{2.73} / \mathrm{CeO}_{2}$ can serve as catalysts and nucleation sites assisting dissociation of hydrogen molecules and formation of $\mathrm{MgH}_{2}$ during hydrogenation. $\mathrm{CeO}_{2}$ was not stable during hydrogenation-dehydrogenation cycles and reverted to $\mathrm{CeH}_{2.73}$ after 20 cycles. Huot et al. [13] investigated filing of magnesium samples and the hydrogenation and dehydrogenation properties of the prepared chips. They reported that the processing of magnesium by filing is a simple and effective approach for preparing magnesium samples with larger surface areas, which makes the samples have higher hydrogenation and dehydrogenation rates than the coarse ones, with air contamination well resisted.

Carboxymethylcellulose, Sodium Salt, $\left[\mathrm{C}_{6} \mathrm{H}_{7} \mathrm{O}_{2}(\mathrm{OH})_{x}\right.$ $\left.\left(\mathrm{C}_{2} \mathrm{H}_{2} \mathrm{O}_{3} \mathrm{Na}\right)_{\mathrm{y}}\right]_{\mathrm{n}},(\mathrm{CMC})$ is a cellulose derivative with carboxymethyl groups $\left(-\mathrm{CH}_{2}-\mathrm{COOH}\right) . \mathrm{CMC}$ is an anionic linear polymer that is water-soluble and nontoxic. CMC melts at a relatively low temperature $(547 \mathrm{~K})$ and is highly viscous.

The addition of CMC may improve the hydrogenation and dehydrogenation properties of $\mathrm{Mg}$ since it has a relatively low melting point and the melting of $\mathrm{CMC}$ during hydride-forming milling (milling in hydrogen) might put the milled samples be in the appropriate states to readily react with hydrogen. In our previous work [14], samples with a composition of $95 \mathrm{wt} \% \mathrm{Mg}$ $+5 \mathrm{wt} \% \mathrm{CMC}$ (named $\mathrm{Mg}-5 \mathrm{wt} \% \mathrm{CMC}$ ) were prepared via hydride-forming milling, and the hydrogenation and dehydrogenation properties of the prepared samples were investigated. Mg-5 wt\%CMC had a very high hydrogenation rate but a low dehydrogenation rate.

Addition of $\mathrm{Ni}$ to $\mathrm{Mg}$ is reported to increase the hydrogenation and dehydrogenation rates of $\mathrm{Mg}$ [4, 15-18]. We chose $\mathrm{Ni}$ as an additive to increase the dehydrogenation rate of $\mathrm{Mg}-5 \mathrm{wt} \% \mathrm{CMC}$.

In this work, samples with a composition of $90 \mathrm{wt} \%$ $\mathrm{Mg}+5 \mathrm{wt} \% \mathrm{CMC}+5 \mathrm{wt} \% \mathrm{Ni}$ were made via milling in hydrogen (hydride-forming milling), and the hydrogenation and dehydrogenation properties of the prepared samples were examined. We designated the samples with the composition of $90 \mathrm{wt} \% \mathrm{Mg}+5 \mathrm{wt} \%$ $\mathrm{CMC}+5 \mathrm{wt} \% \mathrm{Ni}$ as $\mathrm{Mg}-5 \mathrm{wt} \% \mathrm{CMC}-5 \mathrm{wt} \% \mathrm{Ni}$. As far as we know, we are the first to add a polymer CMC and $\mathrm{Ni}$ to $\mathrm{Mg}$ by hydride-forming milling to improve the hydrogenation and dehydrogenation properties of $\mathrm{Mg}$.

\section{EXPERIMENTAL DETAILS}

Pure Mg powder (-20+100 mesh, 99.8\%, metals basis, Alfa Aesar), Ni (Nickel powder average particle 
Table 1 Conditions of hydride-forming milling.

\begin{tabular}{lc}
\hline volume of mill container & $250 \mathrm{~mL}$ \\
\hline total weight of mixture & $8 \mathrm{~g}$ \\
\hline total weight of hardened steel balls & $360 \mathrm{~g} \mathrm{(150} \mathrm{balls)}$ \\
\hline disc rotation speed & $400 \mathrm{rpm}$ \\
\hline hydrogen pressure & $12 \mathrm{bar}$ \\
\hline milling time & $6 \mathrm{~h}$ \\
\hline period of hydrogen refilling & $2 \mathrm{~h}$ \\
\hline
\end{tabular}

size $2.2-3.0 \mu \mathrm{m}$, purity $99.9 \%$ metal basis, C typically $<0.1 \%$, Alfa Aesar), and CMC (Carboxymethylcellulose, Sodium Salt, Aldrich) were used as starting materials to prepare samples by hydride-forming milling.

Hydride-forming milling was performed in a planetary ball mill, a Planetary Mono Mill (Pulverisette 6) from Fritsch. The conditions of the hydride-forming milling are presented in Table 1. Samples were handled in an argon atmosphere.

Variations in the stored and released hydrogen amount were measured according to time using a Sieverts' type hydrogenation and dehydrogenation apparatus previously explained in detail [16]. A half gram of the samples was used for these measurements. The hydrogen pressures were kept nearly constant (in 12 bar for the hydrogenation and in 1.0 bar for the dehydrogenation). After obtaining the dehydrogenation curve (released hydrogen quantity versus time curve), the temperature of the reactor containing the sample was raised to $623 \mathrm{~K}$. During this period, the hydride was decomposed (for about $30 \mathrm{~min}$ ). The reactor was then vacuum-pumped at $623 \mathrm{~K}$ for $1 \mathrm{~h}$.

$\mathrm{X}$-ray diffraction (XRD) diagrams were obtained with $\mathrm{Cu} \mathrm{K} \alpha$ radiation, using a Rigaku D/MAX 2500 powder diffractometer, to analyze phases contained in the samples after hydride-forming milling and after hydrogenation and dehydrogenation cycling. A JSM-5900 scanning electron microscope (SEM) was employed to observe the microstructures of the powders. The scanning electron microscope was operated at $15 \mathrm{kV}$.

\section{RESULTS AND DISCUSSION}

The quantity of hydrogen stored by sample $\mathrm{H}$ was

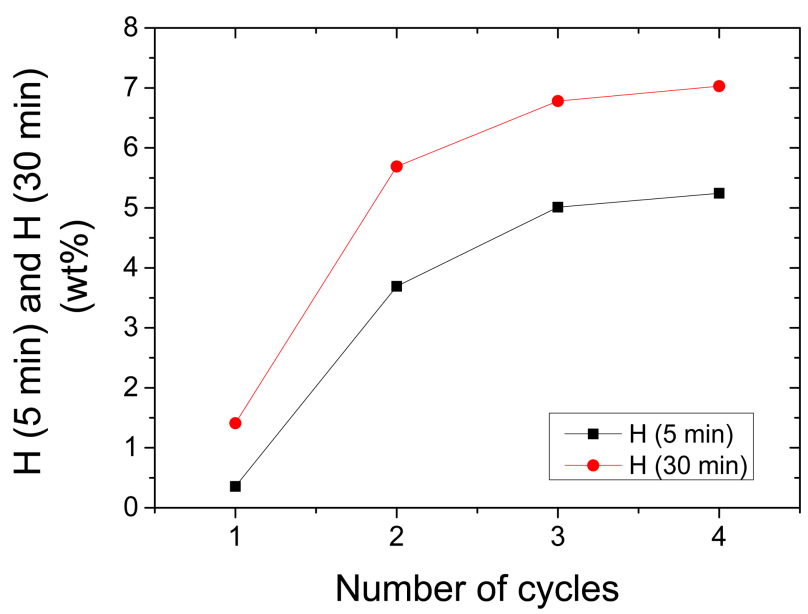

(a)

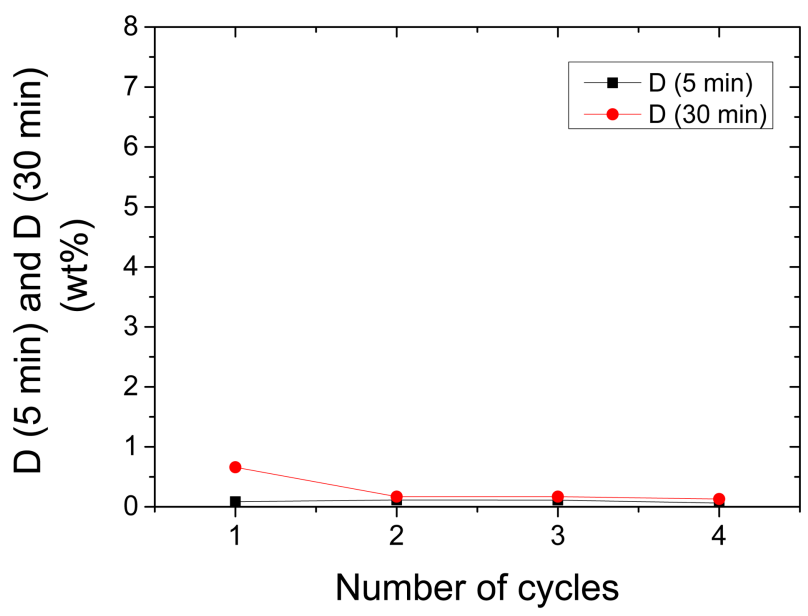

(b)

Fig. 1. Variations in (a) $\mathrm{H}(5 \mathrm{~min})$ and $\mathrm{H}(30 \mathrm{~min})$ in 12 bar hydrogen and (b) D (5 min) and D (30 min) in 1.0 bar hydrogen at $593 \mathrm{~K}$ with the number of cycles, $\mathrm{N}$, for $\mathrm{Mg}-5 \mathrm{wt} \% \mathrm{CMC}$.

calculated using the sample weight as a criterion. The quantity of hydrogen released from sample $\mathrm{D}$ was also calculated using the sample weight as a criterion. The units of $\mathrm{H}$ and $\mathrm{D}$ were weight percent (wt $\%$ ).

The quantities of hydrogen stored for $\mathrm{x}$ min were indicated as $\mathrm{H}$ ( $\mathrm{x}$ min) and the quantities of hydrogen released for $\mathrm{x}$ min were indicated as $\mathrm{D}$ ( $\mathrm{x} \min )$. Figure 1 shows the variations in $\mathrm{H}(5 \mathrm{~min})$ and $\mathrm{H}(30 \mathrm{~min})$ in 12 bar hydrogen and $\mathrm{D}(5 \mathrm{~min})$ and $\mathrm{D}(30 \mathrm{~min})$ in 1.0 bar hydrogen at $593 \mathrm{~K}$ with the number of cycles, $\mathrm{N}$, for $\mathrm{Mg}-5 \mathrm{wt} \% \mathrm{CMC}$. $\mathrm{H}(5 \mathrm{~min})$ and $\mathrm{H}(30 \mathrm{~min})$ of $\mathrm{Mg}-5 \mathrm{wt} \% \mathrm{CMC}$ increased as $\mathrm{N}$ increased. $\mathrm{D}$ ( $5 \mathrm{~min})$ 's of $\mathrm{Mg}-5 \mathrm{wt} \% \mathrm{CMC}$ were very small and similar at 


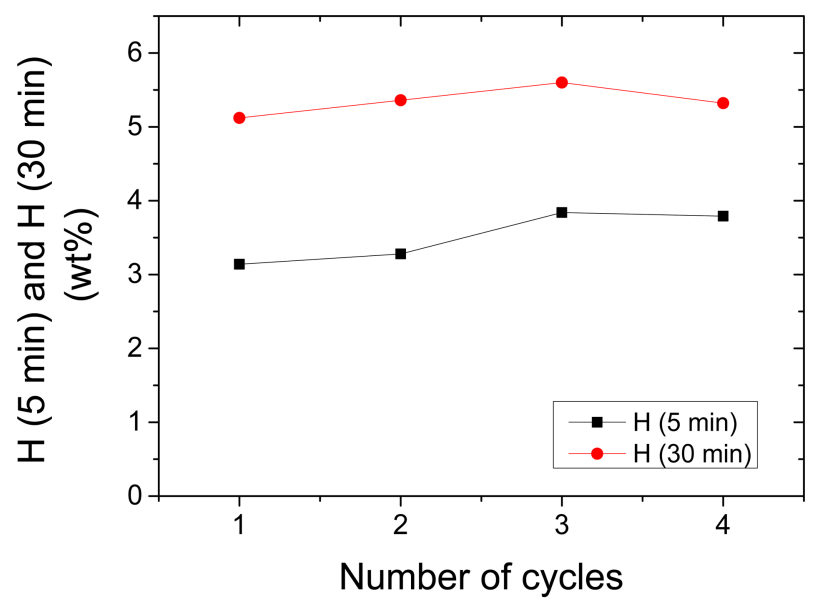

(a)

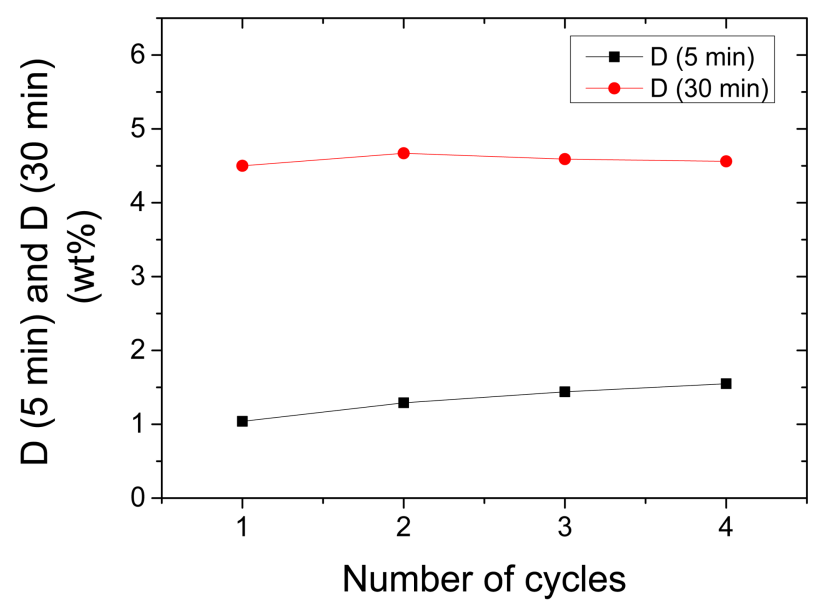

(b)

Fig. 2. Variations in (a) $\mathrm{H}(5 \mathrm{~min})$ and $\mathrm{H}(30 \mathrm{~min})$ in 12 bar hydrogen and (b) D (5 min) and D (30 min) in 1.0 bar hydrogen at $593 \mathrm{~K}$ with the number of cycles, $\mathrm{N}$, for Mg-5 wt $\% \mathrm{CMC}-5 \mathrm{wt} \% \mathrm{Ni}$.

$\mathrm{N}=1-4 . \quad \mathrm{D}(30 \mathrm{~min})$ of $\mathrm{Mg}-5 \mathrm{wt} \% \mathrm{CMC}$ decreased from $\mathrm{N}=1$ to $\mathrm{N}=2$ and $\mathrm{D}(30 \mathrm{~min})$ 's at $\mathrm{N}=2-4$ of $\mathrm{Mg}$ $5 \mathrm{wt} \% \mathrm{CMC}$ were very similar.

The variations in $\mathrm{H}(5 \mathrm{~min})$ and $\mathrm{H}(30 \mathrm{~min})$ in 12 bar hydrogen and $\mathrm{D}(5 \mathrm{~min})$ and $\mathrm{D}(30 \mathrm{~min})$ in 1.0 bar hydrogen at $593 \mathrm{~K}$ with the number of cycles, $\mathrm{N}$, for $\mathrm{Mg}-5 \mathrm{wt} \% \mathrm{CMC}-5 \mathrm{wt} \% \mathrm{Ni}$ are shown in Fig. $2 . \mathrm{H}$ $(5 \mathrm{~min})$ and $\mathrm{H}(30 \mathrm{~min})$ of $\mathrm{Mg}-5 \mathrm{wt} \% \mathrm{CMC}-5 \mathrm{wt} \% \mathrm{Ni}$ increased as $\mathrm{N}$ increased from 1 to 3 , and decreased from $\mathrm{N}=3$ to $\mathrm{N}=4$. At $\mathrm{N}=1, \mathrm{H}(5 \mathrm{~min})$ and $\mathrm{H}(30$ min) of $\mathrm{Mg}-5 \mathrm{wt} \% \mathrm{CMC}-5 \mathrm{wt} \% \mathrm{Ni}$ were much larger than those of $\mathrm{Mg}-5 \mathrm{wt} \% \mathrm{CMC}$, respectively, but from $\mathrm{N}=2$ to $\mathrm{N}=4, \mathrm{H}(5 \mathrm{~min})$ and $\mathrm{H}(30 \mathrm{~min})$ of $\mathrm{Mg}$ -

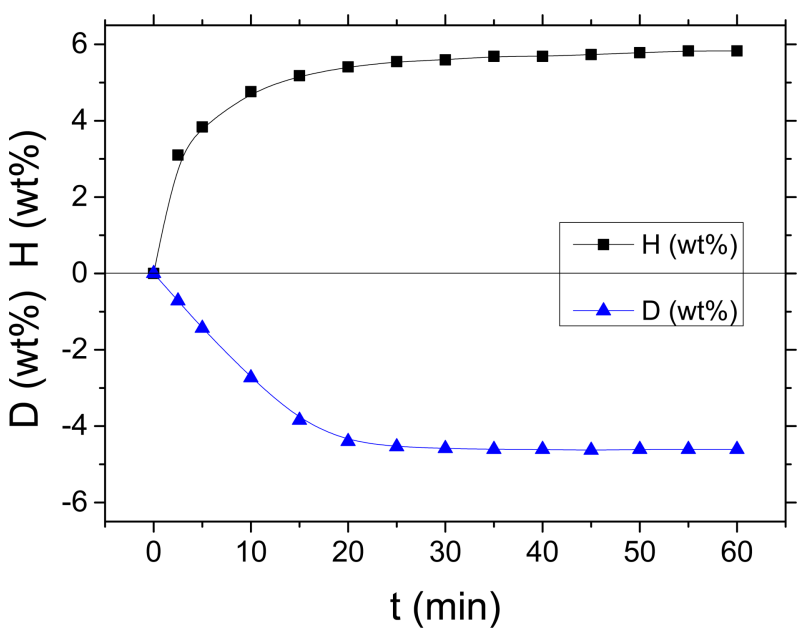

Fig. 3. Hydrogenation curve in 12 bar hydrogen and dehydrogenation curve in 1.0 bar hydrogen at $593 \mathrm{~K}$ at $\mathrm{N}=3$ for Mg5 wt $\%$ CMC-5 wt $\% \mathrm{Ni}$.

$5 \mathrm{wt} \% \mathrm{CMC}-5 \mathrm{wt} \% \mathrm{Ni}$ were smaller than those of $\mathrm{Mg}$ $5 \mathrm{wt} \% \mathrm{CMC}$, respectively. D (5 min) of $\mathrm{Mg}-5 \mathrm{wt} \% \mathrm{CMC}-$ $5 \mathrm{wt} \% \mathrm{Ni}$ increased gradually as $\mathrm{N}$ increased from 1 to 4. $\mathrm{D}(30 \mathrm{~min})$ of $\mathrm{Mg}-5 \mathrm{wt} \% \mathrm{CMC}-5 \mathrm{wt} \% \mathrm{Ni}$ increased from $\mathrm{N}=1$ to $\mathrm{N}=2$ and decreased from $\mathrm{N}=2$ to $\mathrm{N}=4$. However, D (30 min)'s of Mg-5 wt $\%$ CMC- $5 \mathrm{wt} \% \mathrm{Ni}$ were very similar at $\mathrm{N}=1-4$. These results indicate that the activation of $\mathrm{Mg}-5 \mathrm{wt} \% \mathrm{CMC}-5 \mathrm{wt} \% \mathrm{Ni}$ was completed at $\mathrm{N}=3$. D $(5 \mathrm{~min})$ 's and $\mathrm{D}(30 \mathrm{~min})$ 's of Mg$5 \mathrm{wt} \% \mathrm{CMC}-5 \mathrm{wt} \% \mathrm{Ni}$ were much larger than those of $\mathrm{Mg}-5 \mathrm{wt} \% \mathrm{CMC}$, respectively, at $\mathrm{N}=1-4$. This shows that the addition of $\mathrm{Ni}$ to $\mathrm{Mg}-5 \mathrm{wt} \% \mathrm{CMC}$ greatly increased the dehydrogenation rate and cycling performance of $\mathrm{Mg}-5 \mathrm{wt} \% \mathrm{CMC}$.

The hydrogenation curve ( $\mathrm{H}$ versus time $\mathrm{t}$ curve) in 12 bar hydrogen and the dehydrogenation curve (D versus time $\mathrm{t}$ curve) in 1.0 bar hydrogen at $593 \mathrm{~K}$ at $\mathrm{N}=3$ for $\mathrm{Mg}-5 \mathrm{wt} \% \mathrm{CMC}-5 \mathrm{wt} \% \mathrm{Ni}$ are shown in Fig. 3. The hydrogenation rate of Mg- $5 \mathrm{wt} \% \mathrm{CMC}-5 \mathrm{wt} \% \mathrm{Ni}$ was high at the start, decreased gradually, and was very low after about $20 \mathrm{~min}$. Mg- $5 \mathrm{wt} \% \mathrm{CMC}-5 \mathrm{wt} \% \mathrm{Ni}$ stored hydrogen of $3.10 \mathrm{wt} \%$ for $2.5 \mathrm{~min}, 4.76 \mathrm{wt} \%$ for $10 \mathrm{~min}, 5.60 \mathrm{wt} \%$ for $30 \mathrm{~min}$, and $5.83 \mathrm{wt} \%$ for $60 \mathrm{~min}$. The dehydrogenation rate of $\mathrm{Mg}-5 \mathrm{wt} \% \mathrm{CMC}-$ $5 \mathrm{wt} \% \mathrm{Ni}$ was quite high at the start and very low after about $20 \mathrm{~min}$. Mg-5 wt $\% \mathrm{CMC}-5 \mathrm{wt} \% \mathrm{Ni}$ released hydrogen of $0.72 \mathrm{wt} \%$ for $2.5 \mathrm{~min}, 2.73 \mathrm{wt} \%$ for 
Table 2 Variations, with time $\mathrm{t}(\mathrm{min})$, in $\mathrm{H}(\mathrm{wt} \%)$ in 12 bar hydrogen and $\mathrm{D}(\mathrm{wt} \%)$ in 1.0 bar hydrogen of $\mathrm{Mg}-5 \mathrm{wt} \% \mathrm{CMC}-$ $5 \mathrm{wt} \% \mathrm{Ni}$ at $593 \mathrm{~K}$ at $\mathrm{N}=3$.

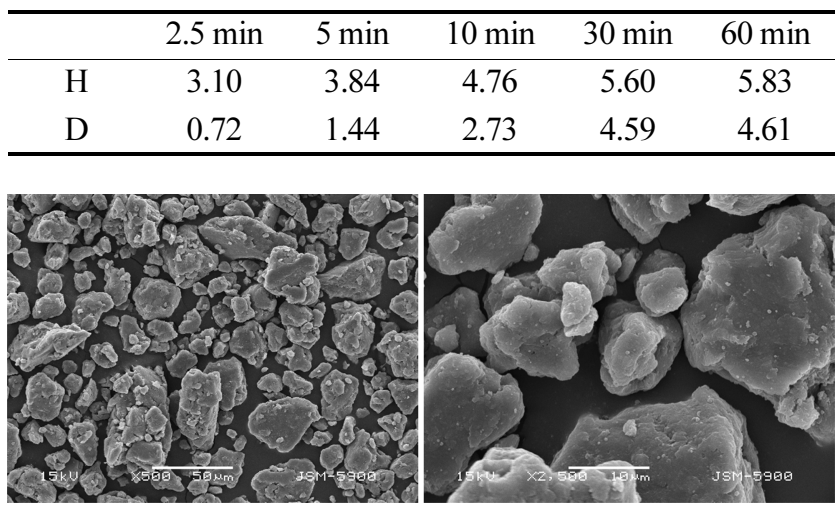

Fig. 4. SEM images of $\mathrm{Mg}-5 \mathrm{wt} \% \mathrm{CMC}$ after hydride-forming milling.

$10 \mathrm{~min}, 4.40 \mathrm{wt} \%$ for $20 \mathrm{~min}$, and $4.61 \mathrm{wt} \%$ for $60 \mathrm{~min}$. Table 2 shows the variations, with time $\mathrm{t}$ (min), in $\mathrm{H}(\mathrm{wt} \%)$ in 12 bar hydrogen and $\mathrm{D}$ (wt\%) in 1.0 bar hydrogen of Mg-5 wt $\%$ CMC-5 wt $\% \mathrm{Ni}$ at $593 \mathrm{~K}$ at $\mathrm{N}=3$.

Figure 4 shows the SEM images of $\mathrm{Mg}-5 \mathrm{wt} \% \mathrm{CMC}$ after hydride-forming milling. The particle size of $\mathrm{Mg}$ $5 \mathrm{wt} \% \mathrm{CMC}$ after hydride-forming milling was not homogeneous and the shapes of the particles were circle or square. The surfaces of the Mg-5 wt\%CMC particles were flat with some small embedded particles.

The SEM images of Mg-5 wt $\%$ CMC-5 wt $\% \mathrm{Ni}$ after hydride-forming milling are shown in Fig. 5. The particle size of Mg-5 wt $\% \mathrm{CMC}-5 \mathrm{wt} \% \mathrm{Ni}$ after hydrideforming milling was not homogeneous. Some particles were fine and large particles were covered with fine particles. The particles of Mg-5 wt $\%$ CMC-5 wt $\% \mathrm{Ni}$ after hydride-forming milling were much smaller than those of $\mathrm{Mg}-5 \mathrm{wt} \% \mathrm{CMC}$ after hydride-forming milling.

Figure 6 shows the SEM images Mg-5 wt $\%$ CMC dehydrogenated at the $4^{\text {th }}$ hydrogenation-dehydrogenation cycle. The particle size was not homogeneous and the shapes of the particles were irregular. The particles had some cracks. The surfaces of the Mg-5 wt\%CMC particles were undulated with some fine embedded particles. The large particles of $\mathrm{Mg}-5 \mathrm{wt} \% \mathrm{CMC}$ dehydrogenated at the $4^{\text {th }}$ cycle were similar to those of $\mathrm{Mg}-5 \mathrm{wt} \% \mathrm{CMC}$ after hydride-forming milling.
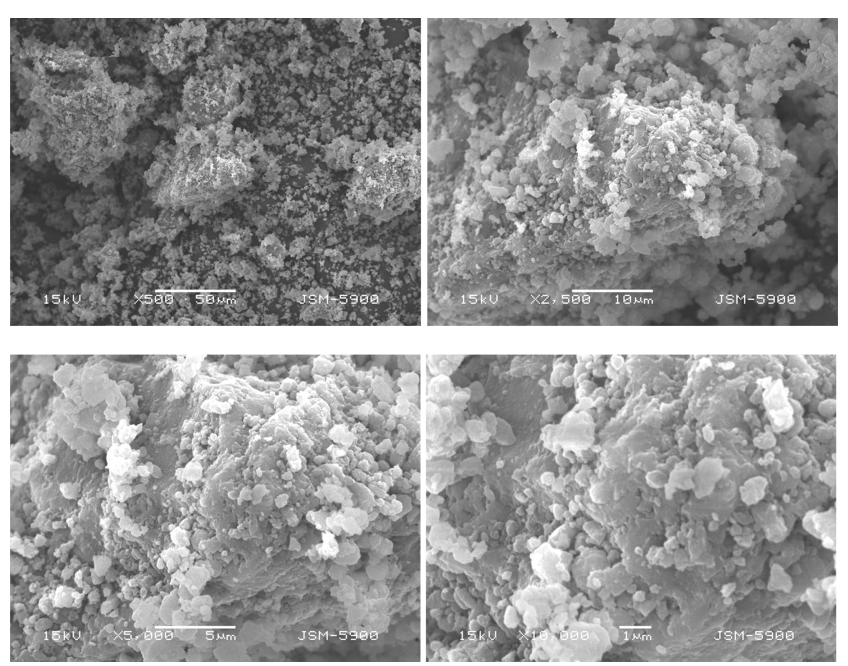

Fig. 5. SEM images of Mg-5 wt $\% \mathrm{CMC}-5 \mathrm{wt} \% \mathrm{Ni}$ after hydrideforming milling.
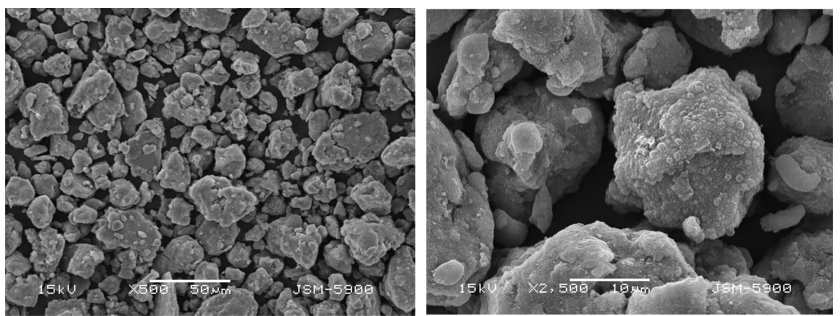

Fig. 6. SEM images of Mg-5 wt $\% \mathrm{CMC}$ dehydrogenated at the $4^{\text {th }}$ hydrogenation-dehydrogenation cycle.

The SEM images of Mg-5 wt\%CMC-5 wt $\% \mathrm{Ni}$ dehydrogenated at the $4^{\text {th }}$ hydrogenation-dehydrogenation cycle are shown in Fig. 7. The particle size was not homogeneous. Some particles were fine and large particles were covered with fine particles. The particles of Mg-5 wt $\% \mathrm{CMC}-5 \mathrm{wt} \% \mathrm{Ni}$ dehydrogenated at the $4^{\text {th }}$ cycle were smaller than those of Mg-5 wt\%CMC$5 \mathrm{wt} \% \mathrm{Ni}$ after hydride-forming milling and much smaller than those of $\mathrm{Mg}-5 \mathrm{wt} \% \mathrm{CMC}$ dehydrogenated at the $4^{\text {th }}$ cycle.

The X-ray diffraction diagram of $\mathrm{Mg}-5 \mathrm{wt} \% \mathrm{CMC}$ $5 \mathrm{wt} \% \mathrm{Ni}$ powder after hydride-forming milling showed that the sample contained $\beta-\mathrm{MgH}_{2}, \mathrm{Mg}$, and small amounts of $\gamma-\mathrm{MgH}_{2}, \mathrm{Ni}$, and $\mathrm{MgO}$. We believe the $\mathrm{MgO}$ had formed by the reaction of $\mathrm{Mg}$ with oxygen adsorbed on the surfaces of particles while the sample was being treated and being exposed to air to obtain 

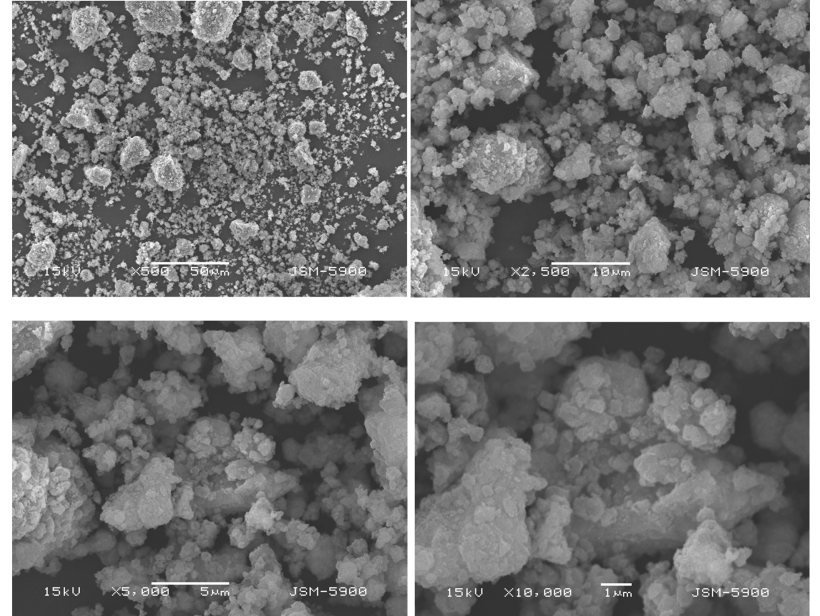

Fig. 7. SEM images of Mg-5 wt $\% \mathrm{CMC}-5 \mathrm{wt} \% \mathrm{Ni}$ dehydrogenated at the $4^{\text {th }}$ hydrogenation-dehydrogenation cycle.

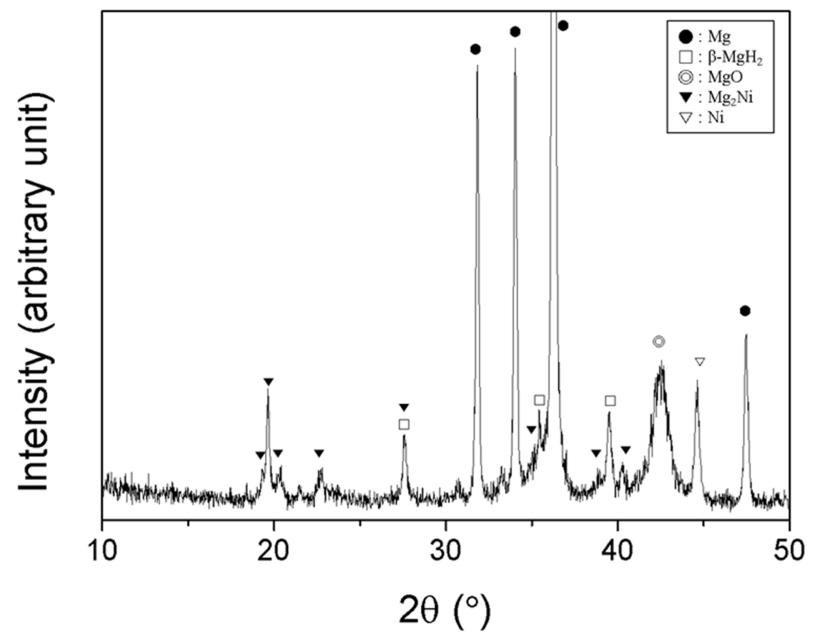

Fig. 8. X-ray diffraction diagram of $\mathrm{Mg}-5 \mathrm{wt} \% \mathrm{CMC}-5 \mathrm{wt} \% \mathrm{Ni}$ powder dehydrogenated at $\mathrm{N}=4$.

the XRD diagram. The background of the XRD diagram was slightly high, showing that the sample was slightly amorphous.

Figure 8 shows the $\mathrm{X}$-ray diffraction diagram of Mg-5 wt $\%$ CMC-5 wt $\% \mathrm{Ni}$ powder dehydrogenated at $\mathrm{N}=4$. The sample contained $\mathrm{Mg}$ and small amounts of $\mathrm{MgO}, \quad \beta-\mathrm{MgH}_{2}, \mathrm{Mg}_{2} \mathrm{Ni}$, and $\mathrm{Ni}$. This shows that $\mathrm{Mg}_{2} \mathrm{Ni}$, which was not observed in the XRD diagram after hydride-forming milling, was formed during hydrogenation-dehydrogenation cycling. We believe that the $\mathrm{MgO}$ had formed by the reaction of $\mathrm{Mg}$ with oxygen adsorbed on the surfaces of particles while the sample was being treated and being exposed to air to obtain the XRD diagram. The background of the XRD diagram was low, indicating that the sample was well crystallized.

We think that the hydride-forming milling of $\mathrm{Mg}$ with $\mathrm{CMC}$ and/or $\mathrm{Ni}$ increases the hydrogenation and dehydrogenation rates by forming imperfections (which make nucleation easy), creating newly exposed reactive surfaces (which increases in the reactivity of $\mathrm{Mg}$ particles with hydrogen) and decreasing the particle size of $\mathrm{Mg}$ (which decreases the diffusion distances of the hydrogen atoms) [19-27]. A comparison of Fig. 4 and Fig. 5 proves that the addition of $\mathrm{Ni}$ to $\mathrm{Mg}-$ $5 \mathrm{wt} \% \mathrm{CMC}$ greatly decreased the particle size during hydride-forming milling. This shows that the addition of $\mathrm{Ni}$ to $\mathrm{Mg}-5 \mathrm{wt} \% \mathrm{CMC}$ strengthened the effects of the hydride-forming milling.

Compared with $\mathrm{Mg}-5 \mathrm{wt} \% \mathrm{CMC}$ after hydride-forming milling [14], Mg-5 wt\%CMC-5 wt\%Ni after hydrideforming milling contained much larger amount of $\beta$ $\mathrm{MgH}_{2}$ and had a higher background in the XRD diagram, showing that the addition of $\mathrm{Ni}$ to $\mathrm{Mg}$ $5 \mathrm{wt} \% \mathrm{CMC}$ led to the preparation of the sample which was much more reactive and more amorphous than the Mg-5 wt\%CMC sample.

Compared with Mg-5 wt \%CMC after hydride-forming milling [14], Mg-5 wt\%CMC-5 wt\%Ni after hydrideforming milling contained a much larger amount of $\beta$ $\mathrm{MgH}_{2}$ and had a higher background in the XRD diagram, which revealed that the addition of $\mathrm{Ni}$ to Mg-5 wt\%CMC produced a sample that was much more reactive and more amorphous than the $\mathrm{Mg}$ $5 \mathrm{wt} \% \mathrm{CMC}$ sample. Figure 2 shows that $\mathrm{Mg}-$ $5 \mathrm{wt} \% \mathrm{CMC}-5 \mathrm{wt} \% \mathrm{Ni}$ had large $\mathrm{H}(5 \mathrm{~min}), \mathrm{H}(30 \mathrm{~min})$, $\mathrm{D}$ (5 min), and $\mathrm{D}$ (30 min).

A comparison of Fig. 6 with Fig. 7 reveals that the addition of $\mathrm{Ni}$ to $\mathrm{Mg}-5 \mathrm{wt} \% \mathrm{CMC}$ greatly decreased the particle size after hydrogenation-dehydrogenation cycling. Figure 8 shows that Mg-5 wt $\% \mathrm{CMC}-5 \mathrm{wt} \% \mathrm{Ni}$ after hydrogenation-dehydrogenation cycling contained the $\mathrm{Mg}_{2} \mathrm{Ni}$ phase. A comparison of Fig. 1(a) with Fig. 2(a) shows that at $\mathrm{N}=1$, the starting hydrogenation rate of $\mathrm{Mg}-5 \mathrm{wt} \% \mathrm{CMC}-5 \mathrm{wt} \% \mathrm{Ni}$ was higher and $\mathrm{H}(30$ 
min) of $\mathrm{Mg}-5 \mathrm{wt} \% \mathrm{CMC}-5 \mathrm{wt} \% \mathrm{Ni}$ was larger than those of $\mathrm{Mg}-5 \mathrm{wt} \% \mathrm{CMC}$, respectively. A comparison of Fig. 1(a) with Fig. 2(a) shows that at $\mathrm{N}=2-4$, the starting hydrogenation rates of $\mathrm{Mg}-5 \mathrm{wt} \% \mathrm{CMC}-5 \mathrm{wt} \% \mathrm{Ni}$ were lower and $\mathrm{H}$ (30 min)'s of $\mathrm{Mg}-5 \mathrm{wt} \% \mathrm{CMC}-5 \mathrm{wt} \% \mathrm{Ni}$ were smaller than those of $\mathrm{Mg}-5 \mathrm{wt} \% \mathrm{CMC}$, respectively. Fig. 1(b) with Fig. 2(b) shows that the addition of $\mathrm{Ni}$ to $\mathrm{Mg}-5 \mathrm{wt} \% \mathrm{CMC}$ greatly increased the dehydrogenation rate and cycling performance of $\mathrm{Mg}$ $5 \mathrm{wt} \% \mathrm{CMC}$.

$\mathrm{Mg}_{2} \mathrm{Ni}$ is known to have higher hydrogenation and dehydrogenation rates than $\mathrm{Mg}$ [28]. The above results show that the addition of $\mathrm{Ni}$ to $\mathrm{Mg}-5 \mathrm{wt} \% \mathrm{CMC}$ strengthened the effects of the hydride-forming milling.

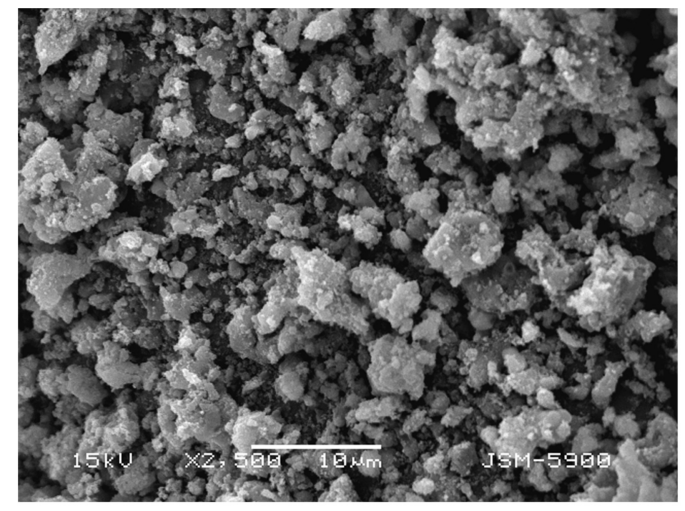

(a)

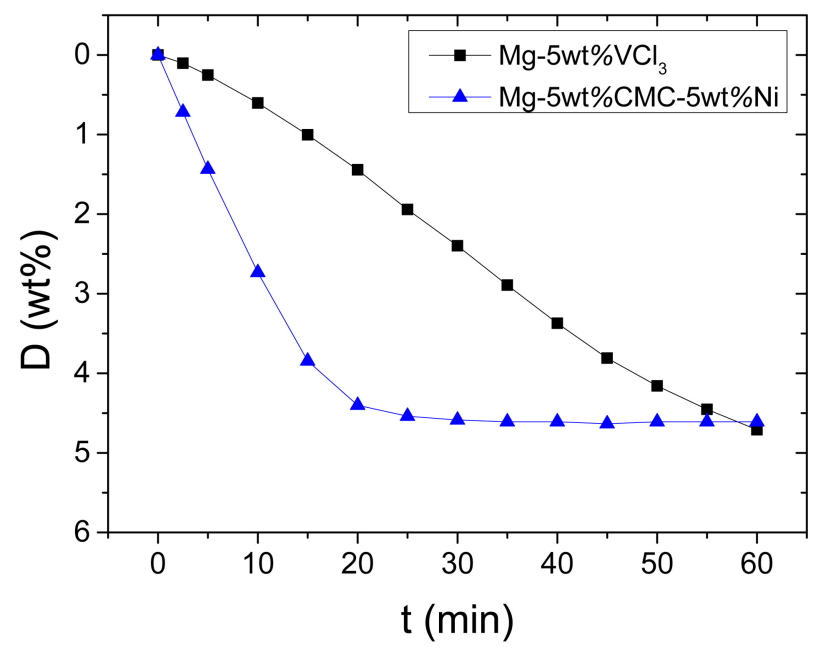

(b)

Fig. 9. (a) A SEM image of $\mathrm{Mg}-5 \mathrm{wt} \% \mathrm{VCl}_{3}$ dehydrogenated at $\mathrm{N}=4$ and (b) dehydrogenation curves of Mg-5 wt $\% \mathrm{CMC}-5 \mathrm{wt} \% \mathrm{Ni}$ and $\mathrm{Mg}-5 \mathrm{wt} \% \mathrm{VCl}_{3}$ at $593 \mathrm{~K}$ in 1.0 bar hydrogen at $\mathrm{N}=3$.
We believe that the $\mathrm{Mg}_{2} \mathrm{Ni}$ formed in $\mathrm{Mg}-5 \mathrm{wt} \% \mathrm{CMC}$ $5 \mathrm{wt} \% \mathrm{Ni}$ during hydrogenation-dehydrogenation cycling made the Mg-5 wt\%CMC-5 wt\%Ni sample have a much higher dehydrogenation rate and a much larger $\mathrm{D}$ (30 min) than the $\mathrm{Mg}-5 \mathrm{wt} \% \mathrm{CMC}$ sample.

Figure 9 shows the SEM image of a sample with a composition of $95 \mathrm{wt} \% \mathrm{Mg}+5 \mathrm{wt} \% \quad \mathrm{VCl}_{3}$ (named $\mathrm{Mg}-5 \mathrm{wt} \% \mathrm{VCl}_{3}$ ) dehydrogenated at $\mathrm{N}=4$ and the dehydrogenation curves of $\mathrm{Mg}-5 \mathrm{wt} \% \mathrm{CMC}-5 \mathrm{wt} \% \mathrm{Ni}$ and $\mathrm{Mg}-5 \mathrm{wt} \% \mathrm{VCl}_{3}$ at $\mathrm{N}=3$ at $593 \mathrm{~K}$ in 1.0 bar hydrogen. Mg-5 wt $\% \mathrm{VCl}_{3}$ dehydrogenated at $\mathrm{N}=4$ had smaller particles than $\mathrm{Mg}-5 \mathrm{wt} \% \mathrm{CMC}-5 \mathrm{wt} \% \mathrm{Ni}$ dehydrogenated at $\mathrm{N}=4$ (Fig. 7). However, Mg-5 wt $\% \mathrm{CMC}-5 \mathrm{wt} \% \mathrm{Ni}$ had a much higher starting dehydrogenation rate and a similar D (60 min) at $\mathrm{N}=3$, compared with $\mathrm{Mg}$ $5 \mathrm{wt} \% \mathrm{VCl}_{3}$. We think that the effect of the $\mathrm{Mg}_{2} \mathrm{Ni}$ formation in the Mg-5 wt\%CMC-5 wt $\% \mathrm{Ni}$ sample increased the starting dehydrogenation rate and that the effects of the $\mathrm{Ni}$ addition to $\mathrm{Mg}-5 \mathrm{wt} \% \mathrm{CMC}$ on the hydride-forming milling also partly contributed to the increase in the starting dehydrogenation rate of the Mg-5 wt\%CMC-5 wt\%Ni sample.

\section{CONCLUSIONS}

We added to increase the dehydrogenation rate of $95 \mathrm{wt} \% \mathrm{Mg}+5 \mathrm{wt} \% \mathrm{CMC}$ (named $\mathrm{Mg}-5 \mathrm{wt} \% \mathrm{CMC}$ ). Samples with a composition of $90 \mathrm{wt} \% \mathrm{Mg}+5 \mathrm{wt} \%$ $\mathrm{CMC}+5 \mathrm{wt} \% \mathrm{Ni}$ (named $\mathrm{Mg}-5 \mathrm{wt} \% \mathrm{CMC}-5 \mathrm{wt} \% \mathrm{Ni}$ ) were made by hydride-forming milling. The activation of $\mathrm{Mg}-5 \mathrm{wt} \% \mathrm{CMC}-5 \mathrm{wt} \% \mathrm{Ni}$ was completed at the $3^{\text {rd }}$ hydrogenation-dehydrogenation cycle. Mg-5 wt\%CMC$5 \mathrm{wt} \% \mathrm{Ni}$ had high dehydrogenation rates, releasing hydrogen of $2.73 \mathrm{wt} \%$ for $10 \mathrm{~min}$ and $4.61 \mathrm{wt} \%$ for $60 \mathrm{~min}$ at $593 \mathrm{~K}$ in 1.0 bar $\mathrm{H}_{2}$ at $\mathrm{N}=3$. The addition of $\mathrm{Ni}$ to $\mathrm{Mg}-5 \mathrm{wt} \% \mathrm{CMC}$ greatly decreased the particle size during hydride-forming milling, showing that the addition of $\mathrm{Ni}$ to $\mathrm{Mg}-5 \mathrm{wt} \% \mathrm{CMC}$ strengthened the effects of the hydride-forming milling. The addition of $\mathrm{Ni}$ to $\mathrm{Mg}-5 \mathrm{wt} \% \mathrm{CMC}$ produced a sample that was much more reactive and more amorphous than the Mg-5 wt\%CMC sample. We believe that the $\mathrm{Mg}_{2} \mathrm{Ni}$ formed in $\mathrm{Mg}-5 \mathrm{wt} \% \mathrm{CMC}-5 \mathrm{wt} \% \mathrm{Ni}$ during 
hydrogenation-dehydrogenation cycling made the $\mathrm{Mg}$ $5 \mathrm{wt} \% \mathrm{CMC}-5 \mathrm{wt} \% \mathrm{Ni}$ sample have a much higher dehydrogenation rate and a much larger $\mathrm{D}$ (30 $\mathrm{min})$ than the Mg-5 wt\%CMC sample. We also believe that the effects of the $\mathrm{Ni}$ addition to $\mathrm{Mg}-5 \mathrm{wt} \% \mathrm{CMC}$ on the hydride-forming milling partly contributed to the increase in the starting dehydrogenation rate of the Mg-5 wt \%CMC-5 wt\%Ni sample.

\section{REFERENCES}

1. B. Sakintuna, F. Lamari-Darkrim, and M. Hirscher, Int. J. Hydrogen Energy 32, 1121 (2007).

2. Z. Li, X. Liu, L. Jiang, and S. Wang, Int. J. Hydrogen Energy 32, 1869 (2007).

3. S. LФken, J. K. Solberg, J. P. Maehlen, R. V. Denys, M. V. Lototsky, B. P. Tarasov, and V. A. Yartys, J. Alloy. Compd. 446-447, 114 (2007).

4. G. Liang, S. Boily, J. Huot, A. V. Neste, and R. Schulz, J. Alloy. Compd. 267, 302 (1998).

5. Z. Yu, Z. Liu, and E. Wang, Mater. Sci. Eng. A 335, 43 (2002).

6. R. Vijay, R. Sundaresan, M. P. Maiya, S. S. Murthy, Y. Fu, H. P. Klein, and M. Groll, J. Alloy. Compd. 384, 283 (2004)

7. X. L. Wang, J. P. Tu, X. B. Zhang, C. P. Chen, and X. B. Zhao, J. Alloy. Compd. 404-406, 529 (2005).

8. S. F. Santos, T. T. Ishikawa, W. J. Botta, and J. Huot, Mater. Chem. Phys. 147, 557 (2014).

9. M. Tian and C. Shang, Int. J. Hydrogen Energy xxx, 1 (2018). (Available online). DOI: 10.1016/j.ijhydene.2018. 02.119

10. J. Huot, H. Hayakawa, and E. Akiba, J. Alloy. Compd. 248, 164 (1997).

11. J. G. Roquefere, J. Lang, A. Yonkeu, J. Dufour, and J. Huot,
Int. J. Hydrogen Energy 36, 2165 (2011).

12. L. Xie, J. Li, T. Zhang, and H. Kou, Renew. Energ. 113, 1399 (2017).

13. A. A. C. Asselli, S. F. Santos, and J. Huot, J. Alloy. Compd. 687, 586 (2016).

14. M. Y. Song, E. Choi, and Y. J. Kwak, Korean J. Met. Mater. 56, 392 (2018).

15. S. H. Hong and M. Y. Song, Korean J. Met. Mater. 54, 125 (2016).

16. Y. J. Kwak, E. Choi, and M. Y. Song, Met. Mater. Int. (2018) (Online publication) https://doi.org/10.1007/s12540-0180055-1

17. M. Y. Song, Y. J. Kwak, and H. R. Park, Korean J. Met. Mater. 54, 503 (2016).

18. S. N. Kwon, H. R. Park, and M. Y. Song, Korean J. Met. Mater. 54, 510 (2016).

19. Y. J. Kwak, S. H. Lee, D. R. Mumm, and M. Y. Song, Int. J. Hydrogen Energy 40, 11908 (2015).

20. S.-H. Hong and M. Y. Song, Met. Mater. Int. 22, 544 (2016).

21. S.-H. Hong and M. Y. Song, Korean J. Met. Mater. 54, 358 (2016).

22. S.-H. Hong and M. Y. Song, Met. Mater. Int. 22, 544 (2016).

23. M. Y. Song, Y. J. Kwak, and H. R. Park, Korean J. Met. Mater. 54, 503 (2016).

24. S. N. Kwon, H. R. Park, and M. Y. Song, Korean J. Met. Mater. 54, 510 (2016).

25. Y. J. Kwak, H. R. Park, and M. Y. Song, J. Nanosci. Nanotech. 17, 8105 (2017).

26. M. Y. Song, S. H. Lee, Y. J. Kwak, and H. R. Park, J. Nanosci. Nanotech. 17, 8132 (2017).

27. H. R. Park, Y. J. Kwak, and M. Y. Song, Korean J. Met. Mater. 55, 656 (2017).

28. J. J. Reilly and R. H. Wiswall, Inorg. Chem. 7, 2254 (1968). 